\title{
Onsite Reference and Instruction Services
}

\section{Setting Up Shop Where Our Patrons Live}

\section{A. Ben Wagner and Cynthia Tysick}

\begin{abstract}
A. Ben Wagner is Sciences Librarian, Science and Engineering Library, Arts and Sciences Libraries, and Cynthia Tysick is Social Sciences Librarian, Lockwood Memorial Library, Arts and Sciences Libraries, University at Buffalo, New York. Submitted for review February 10, 2005; revised and accepted for publication January 26, 2006.
\end{abstract}

Electronic, full-text resources, and online forms have become more and more established in most libraries. As a result, foot traffic has decreased significantly, leading to fewer opportunities for personal contact between librarians and patrons. Innovative outreach efforts are required to counter this trend. In the past two years, some University at Buffalo (UB) librarians have set up office hours in the departments they serve to provide onsite reference and instruction services. This effort has produced unexpected benefits and impediments, and as a result additional outreach mechanisms have been employed or discussed. Overall, the key to successful outreach is attitude, commitment, and consistency. In sum, the experience at UB has shown that there is no substitute for providing a physical presence. The authors believe this approach can be applied in most academic settings and beyond to other types of libraries.

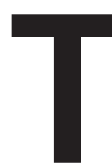

he age of the Internet has brought many advances to libraries, but at a cost. Technological advancements have

Reference \& User Services Quarterly, vol. 46 , no. 4, pp. 60-65

(c) 2007 American Library Association. All rights reserved.

Permission granted to reproduce for nonprofit, educational use. tronic databases are available twentyfour hours a day and can be accessed from home or office. Electronic reference, course reserve, and e-books are never checked out or missing from the shelves. Virtual reference and electronic forms for functions such as renewal and recall of material permit efficient use of both patrons' and librarians' time.

These are not exactly unintended consequences since much of the motivation for instituting electronic subscriptions was to make things as convenient as possible for the patron. In the past, patrons cited traveling to the library during the hours it was open as a major inconvenience. The impact of electronic, Internet-based library resources on the time-honored gate counts, i.e. foot traffic, was expected and is easily verified both subjectively and quantitatively. ${ }^{1}$ However, other consequences, such as the loss of the "personal touch"- opportunities to interact face-to-face and provide "eyes on" and "hands on" instruction and dialogue-have also occurred.

To bring back the personal touch, librarians have responded in a number of ways. They now offer a variety of enticements beyond browsing the bookshelves, such as group study space, coffee shops, extended hours for computer areas, comfortable seating, free printing, 
and wireless networking. ${ }^{2}$ These efforts are commendable, though occasionally they have a negative impact on those desiring a quiet research and study environment. Librarians provide e-mail and online virtual reference. ${ }^{3}$ Finally, librarians have established outreach programs designed to bring library services to wherever the patrons live and work. Brown bag lunches with faculty, workshops, participation in curriculum planning, and attendance at college events are but a few of the techniques described in the literature. ${ }^{4}$

Many academic librarians have described multifaceted approaches at their institutions. Cawthorne noted the importance of marketing efforts and the need to make the library an inviting space for the entire academic community. ${ }^{5}$ Dilmore concluded that the amount of direct contact between librarians and faculty was directly related to the faculty ratings of librarians at nine New England colleges. ${ }^{6}$ Contact opportunities included serving on departmental committees, instructional support, and attendance at social functions. Other articles note the importance of exhibits, kiosks, carefully planned public relations strategies, and a strong role in assisting faculty with information retrieval skills, identification of Internet resources, and integration of technology into the curriculum. ${ }^{7}$ Kraemer, Keyse, and Lombardo describe special efforts via orientation outreach, workshops, and resident hall book clubs to reach underserved student populations such as transfer students and on-campus residents. ${ }^{8}$ Others have described workshops, forums, and Web sites tailored specifically to faculty, getting out of the library to campus events, a dedicated faculty outreach librarian position, and faculty focus groups. ${ }^{9}$

Certainly none of these responsesenticements or outreach-are brand new ideas. After all, within the public library tradition, bookmobiles are a time-honored way to bring libraries to the patrons. Within the more localized community structure of academic institutions, academic libraries are more accustomed to patrons coming to the library premises.
In past decades, many academic libraries have consolidated subject or departmental libraries into more centralized units. Staffing, budgets, and the greatly increasing multidisciplinary nature of nearly all research made centralization nearly inevitable. The redundancy of service points and subscriptions was unsustainable. More recently, the electronic age has allowed librarians to move back to the departments with a virtual rather than physical collection in hand, once again providing services in close proximity to small groups of patrons. To the best of the authors' knowledge, this was first tried and publicized by the Virginia Polytechnic and State University Libraries, although they originally used the rather ambiguous term of "college librarian." ginia Tech has since switched to "field librarian." As a result of dedicating field librarians to specific departments, strong interpersonal ties and interactions between the departments and librarians occurred.

Onsite reference services at the University of Calgary have also been very successful and mirror the experiences at University at Buffalo (UB). ${ }^{11}$ A Weblog created by Reichardt has elicited comments from a number of libraries offering remote reference and instruction services. ${ }^{12} \mathrm{~A}$ variety of titles for onsite librarians are reported in the Weblog, such as "mobile librarians" at the University of Minnesota and "librarians onsite" at the University of Western Ontario.

This article will describe efforts of subject specialist librarians at UB to set up onsite reference services in select academic departments. Although an academic setting is described, many of these techniques can be applied to any situation where patrons are within reasonable travel distance of the reference service.

\section{WHY ONSITE?}

The objective of providing onsite reference and instruction services was to determine if bringing reference services and research consultations to UB's patrons would have any impact on refer- ence and instruction requests. Even the best designed reference services inside libraries tend to be:

- passive-waiting for someone to have the courage to approach the "big desk" with an unfamiliar face behind it; or

- virtual—often anonymous or involving little dialogue, which minimizes the relationship building needed for extended and repeated interactions.

In this virtual world, the authors wanted to see what benefits could still be obtained by engaging in nonvirtual-i.e., in-person-reference and instruction services.

\section{THE UB MODEL}

UB is the largest university in the State University of New York (SUNY) system, with about 28,000 FTEs (full-time equivalent students) on two sizable campuses separated by three miles. The campuses are served by ten library units. Thirty-six librarians have liaison responsibilities to specific academic departments, acting both as collection development specialists and public service librarians. The university libraries offer more than two hundred databases; electronic course reserve and interlibrary loan; Web forms for common library functions such as book renewal; and reference by e-mail, phone, and instant messaging. The university libraries also provide electronic document delivery between UB's two campuses. Hence, except to sign out a book or access a journal that is not available electronically, there are few reasons patrons must physically come to the library. Unfortunately, this is commonplace in academic institutions of all sizes.

The libraries at UB of course have done their best to promote their collections and services, and to provide such benefits as study space, extended hours, and an increased number of computers. Our bibliographic instruction stresses the importance of going beyond general Internet searches or entering a few keywords into an electronic 


\section{FEATURE}

subscription database. The value of print resources and consultations with information professionals are noted at every opportunity. ${ }^{13}$ It is obvious, from discussions with faculty on the quality of research underlying students' papers, that too many students do library research in a cursory manner. Anecdotally, librarians know that nothing replaces a face-to-face reference interview where nonverbal cues can lead the search in a completely new direction.

During the last two years, five subject specialists at UB have piloted onsite reference in seven departments: anthropology, classics, communications, African American studies, industrial engineering, Career Services Center, and physics (see the acknowledgements at the end of this article). The success of this new service varied in each of the departments, but in each case important contacts were made and key lessons learned.

\section{CHOOSING DEPARTMENTS}

Because most subject specialists serve multiple departments, careful thought was given to the most strategic places to start. Factors in this decision included the distance from the physical library, the departmental culture, historical relationships to the library, and the physical space characteristics of the department. For example, one librarian chose physics over chemistry because it is a physically compact department with an obvious main corridor providing easy access to departmental offices. In contrast, the chemistry department is spread over six large floors with offices separated by extensive lab spaces. There is no high traffic area. For a variety of reasons, the physics department felt more isolated from library services. Hence, a strategic decision was made to begin with the department making less use of the library.

The subject specialist for anthropology and classics became involved in onsite reference due in large part to the geographic location of both departments, approximately 0.5 miles from the main campus. Both departments lie in a block of buildings that are com- prised of student dorms, student services, and the departments of geography, anthropology, and classics. Students attending classes in these departments must take a bus from the center of the campus to these outlying buildings. As a result, most faculty and students in anthropology and classics rely on their small departmental libraries (approximately seven thousand volumes each) and electronic products or the Internet. In the end, the most logical location to implement reference services was in their departmental libraries.

\section{GETTING STARTED}

In initial planning, librarians identified visibility, time commitment, scheduling, Internet access, and marketing as key elements. Concerns included sustainability, the time away from the librarian's regular office, and the reliance solely on electronic resources. It was felt that sustainability was a matter of priorities and commitment. The only way to test the value of being in the department versus being in the library was to actually try it. As to the final concern, electronic reference resources have progressed to a point where it was felt that the needs of most patrons could be met using electronic resources alone. The results and conclusions discussed in this paper show that the benefits greatly outweighed any of the potential drawbacks.

In all cases, librarians found the following actions important in initiating onsite reference and instruction services.

\section{Contact Departmental Chair and Negotiate High-visibility "Office" Space}

Typically, the chair of each department was contacted to negotiate a reasonably high-visibility space such as an office in a main corridor, a corner of the reading room, or space close to the departmental office. In one case, a subject specialist serving three departments started the service at the request of one department. When the other two departments found out about it, they, in the true spirit of academic competition, eagerly invited the subject specialist to set up shop in their departments as well.

\section{Limit Time Commitment to a Fairly Small Number of Hours per Week}

The time commitments, given that these were all pilot programs, were small, only 1.5 to 4.0 hours a week during the regular semesters. One important reason to start small is that it is always easier to add service hours as demand warrants, while cutting back hours would be perceived as withdrawing library support for the department.

\section{Avoid Scheduling Conflicts}

Certain commonsense planning went into setting up the office hours. Librarians were committed to guard office hours from other scheduling conflicts. Times were chosen when departmental faculty would be in their offices, and conflicts with major classes and departmental events were avoided.

\section{Bring or Negotiate Equipment with Internet Access}

Given the extensive electronic resources available, equipment needs were minimal. Only a computer with Internet access was essential. Having one's own laptop was useful as one can be familiar with and control the programs on it. A phone and access to a printer was helpful, but as long as one could email results, this was not essential. In one case, the classics librarian was using her own laptop and Ethernet card when the department went wireless. As a show of support for their librarian, the department purchased a wireless card for her use.

\section{Market the Services}

Once space, office hours, and equipment needs were set, the issue of marketing was the next essential task. As with any library service, visibility, email and verbal reminders, pro-active attitude, and other forms of promotion 
are crucial. For example, one's office hours should be mentioned at every bibliographic instruction session conducted for the department. The University of Calgary identified marketing as a key component of their success.

One librarian went so far as to create a "shingle" suspended from two wooden slats that could be taped to the door frame and extend out into the hall during office hours. A colorful graphic from a physics paper and the text "The Physics Librarian is IN" was easily created. The Institute of Physics Publishing (IOPP) badges, flashing the message "Physics turns me on," were a perfect addition, calling attention to the sign without being obnoxious. The shingle caused more comment than any other promotional effort that was tried. The same librarian brought in a sturdy TV tray to place his laptop on so that he could keep an eye on the hallway. Using the existing desk would have meant having his back to the door. Standard enticements such as food, giveaways like the IOPP flashing badges, a name tag, occasional e-mail reminders, and increased visibility at departmental seminars and functions were all part of the promotion efforts.

Before discussing the specific results of onsite reference at UB, it is important to view this effort in the larger context of faculty and student outreach.

\section{Libraries and Outreach}

Patrons respond best to consistency and quality across the entire package of library services and resources. Such a multifaceted approach must take into account the culture and information needs of departments and individuals. At the risk of stating the obvious, exceptional customer service that provides the fast, accurate, and appropriately comprehensive answers or referrals to all patron requests should not be a goal or an occasional achievement, but should be standard operating procedure.

Onsite reference and instruction services are not a magic bullet, making all other forms of outreach redundant. Much has been written about outreach and faculty outreach in particular. Most of the successful models report the use of multiple, targeted techniques including invitations to library workshops and other events, creative orientation activities, involvement in as many departmental academic and social events as possible, visits to faculty and administrators in their offices, and participation in curriculum committees.

Outreach techniques the authors have found particularly effective are:

- attending seminars (especially given by one's own faculty) and other departmental events at least once a month;

- maintaining a list of faculty teaching and research areas;

- exceeding even exceptional customer service standards for the first few requests from any new patron (first impressions count);

- keeping e-mail communications to a minimum, making them as brief and informative as possible;

- targeting graduate student groups, since graduate students teach undergraduate core courses in the departments, conduct their own research, and let other graduate students know where they received good service.

In the specific context of onsite reference services, an important component of being proactive is to seize every opportunity to engage people passing by while being sensitive to the discipline's culture. In the case of physics, the technique of asking leading questions worked the best, especially for those who had "just stopped by to say hi." Questions such as "Any problems using library services or resources?"; "Have you seen SciFinder Scholar yet?"; or "How do you find the information you need?" frequently led to meaningful interactions and demonstrations. Keeping an eye out for passersby and even standing out in the hall from time to time provided many opportunities.

Meanwhile classics faculty and students were more subdued, requiring face-to-face contact through more subtle means such as departmental gradu- ate meetings, visits to faculty during their office hours, and attendance at the numerous off-campus gatherings hosted by faculty throughout the semester. There was little demand from faculty for library instruction, but many requests from graduate students. Therefore, a mid-semester workshop was conducted in the departmental library with every graduate student attending as well as two new faculty members.

\section{RESULTS}

Only a few small signs of appreciation, at best, were expected, given the modest time commitment. The librarians were completely unprepared for the significant good will generated among the faculty by this single service. They spoke of it to colleagues and visitors with obvious pride. This one action communicated, in a way that years of other efforts had not, that the library really cares about this department and wants to help. One librarian received a warm, thank-you e-mail just for announcing the office hours before they had even begun. The long-term impact of this good will should not be underestimated. In the case of the physics department, the entire relationship to the library has been transformed into a far more positive one.

Another unexpected benefit was meaningful contact with students from other majors who happened to be taking department courses. In one notable case, an extensive demonstration of INSPEC was provided by the physics librarian to a computer science student with an interest in virtual reality. He had never heard of INSPEC before this and was amazed (as students so often are) at the high-quality, scholarly material so readily available in subscription databases.

It was clear from both verbal and nonverbal cues that many of the questions and interactions would never have taken place had so much as an e-mail or phone call been required. The most common opening line ran something like this, "I was just passing by and was wondering if. ..."

Above all, the pilot program dem- 


\section{FEATURE}

onstrated that face-to-face encounters have significant advantages over e-mail and virtual interactions. The interactions were immediate, visual, high impact, tailored, and personal. The more relaxed atmosphere of a department office, as opposed to the typical openreference-desk environment, permitted follow-up questions that often led to extended instructional opportunities. A casual question about finding an article could lead into a discussion of interlibrary loan, finding electronic fulltext, and why everything is not available electronically. This could lead to a discussion of research interests and an opportunity to demonstrate a few key databases, retrieving citations of immediate interest.

In general, the number of quality interactions usually matched a "good" shift at the reference desk, one to two per hour after one factors out all the important but routine directional questions and equipment problems. Certainly there were slow weeks and never long lines outside the office. Still it is expected that in the long term, opportunities will continue as information needs arise.

Opportunities frequently have opened up beyond whatever office hour interactions occur. In one case, a librarian set up office hours in the department chair's outer office area with an accompanying e-mail announcement from the chair to the entire department. Though only a few students took advantage of the office hours, the librarian noted a marked increase in the number of students from that particular department e-mailing requests and setting up appointments in the science and engineering library. The announcement by the chair had given the librarian new visibility and "imprimatur." In other cases, it has led to sitting in on search committee interviews, positions on library development committees, invitations to important networking social events, and even an opportunity for joint publication with a faculty member. Clearly, evaluating onsite office hours only on the basis of number of transactions per hour is inadequate and misleading.

\section{CONCLUSIONS}

Though it would be false to say each attempt was uniformly successful, overall these efforts have proved to be sustainable. As long as one starts with just a few hours each week and has management support, the impact on one's schedule is not dramatic. The librarians at UB have been in the process of combining service points, partly to free up staff time for departmental outreach. Students and faculty are also encouraged to set up appointments so that high-quality, subject-specific consultations can be provided.

The visibility and interactions resulting from being in the department far exceed any benefit from sitting in the libraries' regular offices. The real scheduling problem is not the few hours of departmental reference, but rather the many hours of meetings in a typical week.

With academics usually needing background information and a limited number of good references in an initial consultation, there have been few problems using only electronic sources. It is always possible to arrange follow-up consultations back at the library.

For all of the advances in virtual reference-service delivery technology, face-to-face interactions should not be abandoned. Onsite departmental reference services are not the complete answer for patron outreach. It works best within the larger context of faculty and student outreach activities that intentionally build long-term relationships with the department, such as attendance at faculty seminars and departmental events. Nor does it replace e-mail, phone consultations, instant messaging, general exceptional customer service, and library-based reference services and appointments.

However, in the right settings, onsite reference has been the single most effective service for communicating a direct interest in the information needs of both faculty and students in a department. Librarians generate good will and open the door for additional interactions by spending even a few hours "onsite." The keys are to be persistent, seize every opportunity, be patient, and keep trying various strategies until something works.

Acknowledgments: The authors wish to thank Margie Wells, director of Public Services, and Austin Booth, director of Collections, both of the Arts and Sciences Libraries, University at Buffalo, for their encouragement to pursue innovative projects. This article was enriched by the many helpful conversations with other University at Buffalo subject-specialist librarians piloting onsite departmental reference services including Nancy Schiller (engineering); Glendora Johnson-Cooper (African American studies); and Chris Hollister (Career Services Center).

\section{References}

1. Scott Carlson, "The Deserted Library," Chronicle of Higher Education 48, no. 12 (Nov. 2001): A35-A38; Charles B. Lowry, "Re-Positioning Libraries: A Consideration of the Obstacles," Portal-Libraries and the Academy 3, no. 2 (Apr. 2003): VII-XI; Harold B. Shill and Shawn Tonner, "Does the Building Still Matter? Usage Patterns in New, Expanded, and Renovated Libraries, 1995-2002," College $\&$ Research Libraries 65, no. 2 (Mar. 2004): 123-50; and Frieda Weise, "Being There: The Library as Place," Journal of the Medical Library Association 92, no. 1 (Jan. 2004): 6-13.

2. Debra Engel and Karen Antell, "The Life of the Mind: A Study of Faculty Spaces in Academic Libraries," College \& Research Libraries 65, no. 1 (Jan. 2004): 8-26; Donald E. Riggs, "New Libraries Remain an Excellent Investment," College \& Research Libraries 63, no. 2 (Mar. 2002): 108-09; and Harold B. Shill and Shawn Tonner, "Creating a Better Place: Physical Improvements in Academic Libraries, 1995-2002," College \& Research Libraries 64 , no. 6 (2003): 431-66.

3. Tam Hoskisson and Deleyne Wentz, "Simplifying Electronic Reference: A Hybrid Approach to One-on-One Consultation [at Utah State University]," College \& Undergraduate Libraries 8, no. 2 (2001): 89-102; Sherry Engle Moeller, "AskA-Librarian: An Analysis of an E-Mail Reference Service at a Large Academic Library," Internet Reference Services Quarterly 8, no. 3 (2003): 47-61; Jana Ronan, "The Reference Interview Online," Reference \& User Services Quarterly 43, no. 1 (Fall 2003): 43-47; Mohamed Taher "The Reference Interview through Asyn- 
chronous E-Mail and Synchronous Interactive Reference: Does It Save the Time of the Interviewee?" Internet Reference Services Quarterly 7, no. 3 (2002): 23-34; and Susan A. Ware, et. al., "Ask a Penn State Librarian, Live: Virtual Reference Service at Penn State," The Reference Librarian 38, no. 79/80 (2002/2003): 281-95.

4. Richard Raspa and Dane Ward, eds., The Collaborative Imperative: Librarians and Faculty Working Together in the Information Universe (Chicago: ACRL, 2000); Wade R. Kotter, "Bridging the Great Divide: Improving Relations between Librarians and Classroom Faculty," Journal of Academic Librarianship 25, no. 4 (1999): 294-303.

5. Jon E. Cawthorne, "Integrating Outreach and Building Partnerships: Expanding Our Role in the Learning Community," College \& Research Libraries News 64, no. 10 (Nov. 2003): 666-69, 681.

6. Donald H. Dilmore, "Librarian/Faculty Interaction at Nine New England Colleges," College \& Research Libraries 57 (May 1996): 274-84.
7. Ada M. Ducas and Nicole MichaudOystryk, "Toward a New Enterprise: Capitalizing on the Faculty/Librarian Partnership," College \& Research Libraries 64, no. 1 (Jan. 2003): 55-74; Carole Ann Fabian et al., "Multiple Models for Library Outreach Initiatives," Reference Librarian 39, no. 82 (2003): 39-55.

8. Elizabeth W. Kraemer, Dana J. Keyse, and Shawn V. Lombardo, "Beyond These Walls: Building a Library Outreach Program at Oakland University," Reference Librarian 39, no. 82 (2003): 5-17.

9. Linda Reeves et al., "Faculty Outreach: A Win-Win Proposition," Reference Librarian 39, no. 82 (2003): 57-68; Scott Stebelman et al., "Improving Library Relations with the Faculty and University Administrators: The Role of the Faculty Outreach Librarian," College \& Research Libraries 60, no. 2 (Mar. 1999): 121-30.

10. Jane E. Schillie, Virginia E. Young, and Susan A. Ariew, "Outreach through the College Librarian Program at Virginia Tech," Reference Librarian 34, no. 71 (2000): 71-78; Nancy H. Seamans and Paul Metz, "Virginia Tech's Innovative
College Librarian Program," College \& Research Libraries 63, no. 4 (2002): $324-$ 32.

11. Jennifer Lee, K. Alix Hayden, and Don MacMillan, "Wouldn't Have Asked for Help if I Had to Go to the Library': Reference Services On Site," Issues in Science and Technology Librarianship 41 (Fall 2004). www.istl.org/04-fall/index.html (accessed Dec. 10, 2004).

12. Randy Reichardt, Responses to the Question: Does Your Library Offer Remote Reference Information Services? [Web Log], stlq.info/archives/000955.html (accessed Apr. 21, 2004).

13. Juris Dilevko and Lisa Gottlieb, "Print Sources in an Electronic Age: A Vital Part of the Research Process for Undergraduate Students," Journal of Academic Librarianship 28, no. 6 (2002): 381-92; Frieda Weise, "Being There: the Library as Place," Journal of the Medical Library Association 92, no. 1 (Jan. 2004): 6-13.

\section{OUTSTANDING REFERENCE SOURCES CONTINUED FROM PAGE 52}

Oxford Encyclopedia of Children's Literature. Jack Zipes, ed. 4 vols. Oxford, 2006. \$495 (ISBN 0-19-514656-5).

Qu'ran: An Encyclopedia. Oliver Leaman, ed. 771p. Routledge, 2005. \$225 (ISBN 0-415-32639-7).
Right, Wrong, and Risky: A Dictionary of Today's American English Usage. 570p. Norton, 2005. \$29.95 (ISBN 0-39306119-1). 